\title{
Understanding the Performance of a Bisphosphonate Ru Water Oxidation Catalyst
}

Received 00th January 20xx Accepted 00th January 20xx

DOI: $10.1039 / \times 0 \times x 00000 x$
Jesús A. Luque-Urrutia, ${ }^{a}$ Jayneil M. Kamdar, ${ }^{\mathrm{b}}$ Douglas B. Grotjahn, ${ }^{* b}$ Miquel Solà, ${ }^{* a}$ and Albert Poater*a

Water oxidation catalysts (WOCs) are a key part of generating $\mathrm{H}_{2}$ from water and sunlight, consequently, it is a promising process for the production of clean energy. The mechanism of water oxidation mediated by Ru(2,2'-bipyridine-6, $6^{\prime}$ diphosphonato)(4-picoline) ${ }_{2}$ has been studied computationally to comprehend the results obtained in the experiments performed by the Concepcion and Grotjahn groups. Our study was performed at $\mathrm{pH}=8$ and 1 . At $\mathrm{pH}=8$, the phosphonates are fully deprotonated and the catalysis, which is shown to be more energetically costly than that of the dicarboxylato Ru catalyst counterpart, takes place through a mechanism that involves a bimolecular interaction between two metal-oxo units $(\mathrm{I} 2 \mathrm{M})$. At $\mathrm{pH}=1$, only one of the phosphonates of the catalyst is deprotonated. After testing all possible pathways and comparing with experimental data, we determine that the catalysis proceeds neither through a water nucleophilic attack nor via I2M, instead, we hypothesize that it takes place thanks to an I2M interaction between the catalyst and the ceric ammonium nitrate.

Keywords: water oxidation, ruthenium, phosphonate, cerium, catalysis, CAN, I2M, WNA

\section{Introduction}

In situ hydrogen generation has been a hot topic during recent years due to the increasing need for clean fuel production with a high energy output. $1,2,3$ To reach a sustainable reaction for $\mathrm{H}_{2}$ production the use of cheap raw materials and catalysts have been the main focus of research. Accordingly, water as a reactant is an obvious choice due to its availability and its proton reduction and wate oxidation reactions. Due to the harsh conditions required to perform the water oxidation process, researchers have been trying to develop different water oxidation catalysts (WOCs).4,5 The first molecula WOC found by Meyer et al. known as the "blue dimer", 6,7 inspired many other researchers to perform this kind of catalysis with different transition metals, such as $\mathrm{Ru}^{8,9,10}$ or Ir. ${ }^{11,12}$ Many catalysts involving Ru have been developed, but one of the most interesting is the 2,2-bipyridine-6,6-dicarboxylic acid (bda) Ru catalyst (A), which was first explored by Sun, ${ }^{13}$ Privalov, ${ }^{14}$ and Llobet et al. ${ }^{15}$ It performs WOC efficiently, partly due to the large O-Ru-O angle ( 123ㅇ) that the bda infers to the catalyst. This angle provides a gap for a water molecule to interact with an octahedral Ru intermediate, ${ }^{16}$ forming a

\footnotetext{
-Institut de Química Computacional i Catàlisi and Departament de Química,

Universitat de Girona, c/ Mํo Aurèlia Capmany 69, 17003 Girona, Catalonia, Spain. E-mail: albert.poater@udg.edu

Department of Chemistry and Biochemistry, San Diego State University, 5500 Campanile Drive, San Diego, CA, US 92182-1030.

Electronic Supplementary Information (ESI) available: Computational details and all XYZ coordinates, energies and 3D structures of all species. Se DOI: $10.1039 / \times 0 \times x 00000 \times$
}

hepta-coordinated compound. . $^{17,18}$ This peculiar seven-coordinated structure appears to lower overpotentials required for the oxidative steps while emulating the activity of the WOC in Photosystem II. ${ }^{19}$ Even though there are already some studies which focus on the exchange of axial ligands, such as pyridine, picoline or isoquinoline, ${ }^{20}$ with the conclusion that the bda remains mostly unchanged, ${ }^{21}$ the hepta-coordinated metal center $22,23,24$ is fundamental for the stabilization of higher oxidation sates of the ruthenium. ${ }^{17}$

Towards the development of more efficient catalysts, in 2016 Grotjahn et al. ${ }^{25}$ and Concepcion et al. ${ }^{26}$ reported Ru(2,2'-bipyridine$6,6^{\prime}$-diphosphonato)(picoline)2, B, a phosphorus analog of the $\mathrm{Ru}(\mathrm{bda})$ catalyst (Figure 1 ) with the novel ligand $\mathrm{bpaH}_{2}$. The largest difference between the bda (A) and $\mathrm{bpaH}_{2}$ (B) ligands is that the $\mathrm{bpaH}_{2}$ has phosphonate groups instead of carboxylate groups. Each of the phosphonates groups are monoanionic like the carboxylates but depending on the $\mathrm{pH}$, they can become dianionic thanks to their hydroxyl group. In basic media, the doubly deprotonated bpa ligand results in four negative charges (as opposed to two negative charges with the biprotonated bpa at $\mathrm{pH}=1$ or the bda) that stabilize the higher oxidation states of the $\mathrm{Ru}$ center. Furthermore, the hydroxyl/hydroxo group is able to help in proton transfer reactions. 

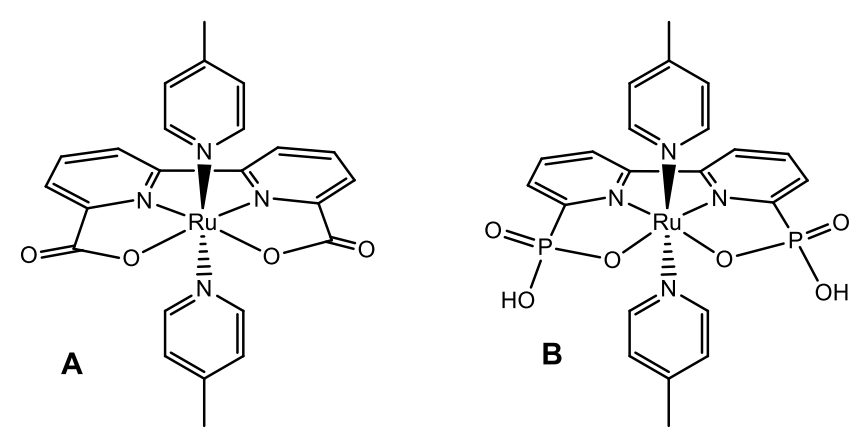

Figure 1. WOC catalysts A (with dicarboxylato ligand (bda)) and B (with diphosphonato ligand $\left(\mathrm{bpaH}_{2}\right)$ ) studied in this work.

From past studies, ${ }^{17,25,27}$ two important conclusions were drawn in relation to the performance of the catalysts included in Figure 1: the dicarboxylato catalyst $\mathbf{A}$ generally outperforms the diphosphonato catalyst B with lower overpotentials and higher TOFs, even though there is not a clear understanding of the reason. On the other hand under acidic conditions $(\mathrm{pH}=1)$, the phosphonate catalyst appears to need ceric ammonium nitrate (CAN) for the reaction to progress. It is worth noting that CAN works under mid to low $\mathrm{pH}$, otherwise it precipitates. ${ }^{28} \mathrm{At} \mathrm{pH}=8$ and $\mathrm{pH}=1$ without $\mathrm{CAN}$, the catalytic activity is minimal if any.

WOC testing using sacrificial oxidants has been performed with sodium peroxodisulfate, ${ }^{29}$ potassium peroxymonosulfate, ${ }^{30}$ as well as many others. ${ }^{31,32}$ However, one of the most used oxidants is the $\mathrm{Ce}^{\mathrm{IV}}$ reagent CAN. It accepts one electron, forming Ce $\mathrm{Clll}^{\mathrm{II}}, 3 \mathrm{a}$ ane electron change that is relevant to operation of a photoelectrochemical cell. In many, but not all cases, it has been shown that the WOC catalysts that work with CAN also work electrochemically. ${ }^{34}$ A notable exception observed by the Grotjahn group is that $\mathbf{B}$, and a derivative with OPr groups in place of $\mathrm{OH}$ groups, at $\mathrm{pH}=1$ were active catalysts using CAN, but mostly inactive electrochemically, even when driven to $1.8 \mathrm{~V}$ potential. In CANdriven reactions of B. Concepcion's group observed first-orde dependence of reaction rate on both concentrations of $\mathbf{B}$ and CAN Taken together, these findings strongly implicate a non-innocent role for CAN; Costas and Lloret-Fillol, et al. ${ }^{35}$ have suggested with iron based catalysts that CAN interacts with the catalyst to reduce some barriers by making a dimer between two different metal complexes, and more recently this has been also checked by Cavallo and Macchioni, et al. ${ }^{36}$ for iridium catalysts. Similarly, Sakai's group ${ }^{37}$ has suggested $\mathrm{Ce}-\mathrm{OH}-\mathrm{Ru}$ interaction during CAN-driven WOC. Nevertheless, Ertem, Roth, Llobet et al. ${ }^{38}$ reported that when testin the $\mathrm{O}-\mathrm{O}$ bond formation through ${ }^{18} \mathrm{O}$ kinetic isotopic effects, the CAN does not intervene in the bond formation, but it can help to oxidize the catalyst prior to that.

Finally, there are two commonly proposed mechanistic pathways fo WOC: a bimolecular interaction between two metal-oxo units (I2M) and a mononuclear water nucleophilic attack (WNA).39,40,41 For the dicarboxylato catalyst $\mathbf{A},{ }^{15}$ experiments performed by Ahlquist, Sun, et al. ${ }^{42}$ have shown that while the majority of Ru catalysts operate by the WNA mechanism, A operates by the I2M mechanism. 43,44 In the case of the phosphonate catalyst $\mathbf{B}^{20 \mathrm{a}}$ available evidence suggests WNA mechanism operates; nevertheless here we will analyze both WNA and I2M mechanistic possibilities.

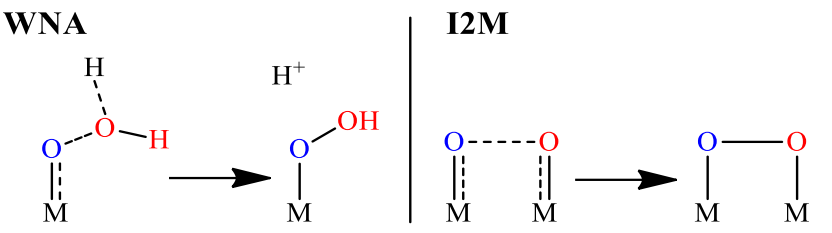

Scheme 1. O-O Bond formation for the WNA mechanism (left) and the I2M mechanism (right).

All in all, we wanted to delve deeper in understanding the behavior of this phosphonate catalyst, which is $\mathrm{pH}$ responsive due to the phosphonate ligands.

\section{Computational Details}

All DFT calculations were performed with the Gaussian09 set of programs, ${ }^{45}$ using the M06L functional. ${ }^{46,47}$ The electronic configuration of the molecular systems was described with the standard split-valence basis set with a polarization function of Ahlrichs and co-workers for $\mathrm{H}, \mathrm{C}, \mathrm{N}, \mathrm{O}$ and $\mathrm{P}$ (SVP keyword in Gaussian). ${ }^{48}$ The small-core quasi-relativistic Stuttgart/Dresden effective core potential, with an associated valence basis set (standard SDD keywords in Gaussian09) was used for Ru. ${ }^{49,50,51}$ The geometry optimizations were performed without symmetry constraints, and analytical frequency calculations were carried out to characterize the located stationary points. These frequencies were used to calculate unscaled zero-point energies (ZPEs) as well as thermal corrections and entropy effects at $298 \mathrm{~K}$ and $1354 \mathrm{~atm}$ to better simulate molecular proximity ${ }^{52}$ by using the standard statistical mechanics relationships for an ideal gas. A pressure 1354 atm was consider in the calculations as recommended by Martin et al., 52 who determined that this pressure defines the ideal water gas including the relative pressure performed by the surrounding water solvent in aqueous media. ${ }^{53,54}$ Energies were obtained by single-point calculations on the optimized geometries with the triple-? basis set of Weigend and Ahlrichs for main-group atoms (TZVP keyword in Gaussian), ${ }^{55}$ whereas for ruthenium the SDD basis set was employed. Solvent effects were included with the polarizable continuous solvation model PCM using $\mathrm{H}_{2} \mathrm{O}$ as solvent. ${ }^{56,57}$ The reported Gibbs energies in this work include energies obtained at the M06L/TZVP SDD//M06L/SVP SDD level of theory corrected with zero-point energies, thermal corrections, and entropy effects evaluated at $298 \mathrm{~K}$ and $1354 \mathrm{~atm}$ with the M06L/SVP SDD method.

To evaluate the $\mathrm{pK}_{\mathrm{a}}$ in transition metal complexes that hold ligands, we have used the following procedure:

$\mathrm{AOH} \rightarrow \mathrm{AO}^{-}+\mathrm{H}^{+}$

$p K_{a}=-\log \left(e^{-\frac{\Delta G}{R T}}\right)$

Using experimental $\mathrm{pK}_{\mathrm{a}}$ values versus our calculated results, we have adjusted a regression line that provides more reliable $\mathrm{pK}_{\mathrm{a}}$ values that the direct use of Eq. (1) (see Supporting Information). The proton energy used for the $\mathrm{pK}_{\mathrm{a}}$ is $\Delta \mathrm{G}=-270.3 \mathrm{kcal} / \mathrm{mol}$, which includes the translational entropy correction. ${ }^{58}$

We represent both proton coupled electron transfer (PCET) and redox reactions ${ }^{59}$ with Eqs. 2 and 3:

$A^{+}+e^{-} \rightarrow A$

$\varepsilon_{\text {red }}^{0}=\frac{\Delta G}{-n F}-S H E$,

where $\Delta G$ is the Gibbs energy of the reaction, $S H E$ refers to the absolute potential of the Standard Hydrogen Electrode $(4.28 \mathrm{~V})$ in 
water, ${ }^{60} \mathrm{n}$ refers to the number of electrons and $\mathrm{F}$ is the Faraday constant. Energies are given in $\mathrm{kcal} / \mathrm{mol}$ and the reduction potential $\varepsilon$ in $\mathrm{V}$.

Since PCET reactions include $\Delta G_{H^{+}}$, we use Eq. 4:

$\varepsilon_{\text {red }}^{0}=\frac{\Delta G_{M^{n} \mathrm{OH}_{2}}-\Delta G_{M^{n+1} \mathrm{OH}^{-0.5} \cdot \Delta G_{\mathrm{H}_{2}}}}{-n F}$

Using this methodology, we can determine the reduction potential for the PCET reactions without experimental values. ${ }^{61}$ For more information, check the Supporting Information. Finally, due to the analysis of different $\mathrm{pH}$ conditions, we applied the Nernst equation approximation for the PCETs at $298 \mathrm{~K}$ and atmospheric pressure:

$\varepsilon=\varepsilon_{\text {red }}^{0}-0.0591 \cdot p H$

$\varepsilon$ is the corrected PCET reduction potential considered in the mechanisms at the given $\mathrm{pH}$ value.

\section{Results and Discussion}

The reaction mechanisms depicted in Figures 2 and 3 constitute summary of the most relevant paths of the full reaction mechanisms that can be found in the Supporting Information. Molecula structures $\mathbf{Y}$ in the reaction mechanisms are labelled $\mathbf{x} \mathbf{Y}$, where $X$ indicates spin state $(1=$ singlet, $2=$ doublet, $3=$ triplet, $4=$ quadruplet) and $q$ is the total charge of species $Y$.

Mechanism at $\mathrm{pH} 8$. The diagram in Figure 2 outlines the most likely mechanistic scenarios at $\mathrm{pH}=8$ starting from the $\mathrm{Ru}^{\prime \prime}$ species $\mathbf{B}$ (= $\left.\left[{ }^{[R u l l}\right]_{0}\right)$ to the Ruv species $\left(=\left[R^{v}=0\right]^{1-}\right.$ ) (See SI for the full figure). The Grotjahn and Concepcion groups independently measured a $\mathrm{pK}_{\mathrm{a}}$ of approximately 4 for simultaneous deprotonation of both phosphonate moieties of [Ru" $]^{0}$. As seen in Figure 2, our estimates for the first and second deprotonation $\mathrm{pK}_{\mathrm{a}}$ of [ $\left.\mathrm{Ru}^{\prime \prime}\right]^{0}$ are 4.7 and 5.3 . At $\mathrm{pH}=8$, the reaction mechanism starts with Rull species [Ru" ${ }^{2-}$ with a net charge of -2 . From [Ru" $]^{2-}$, either one-electron oxidation

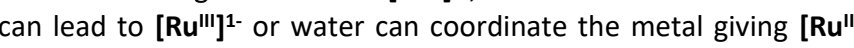
$\left.\mathrm{OH}_{2}\right]^{2-}$, however, looking into previous work on similar catalysts ${ }^{62}$ we assume that the oxidation step is preferred, reaching therefore $\left[\mathbf{R u}^{\mathrm{II}}\right]^{1-}$.

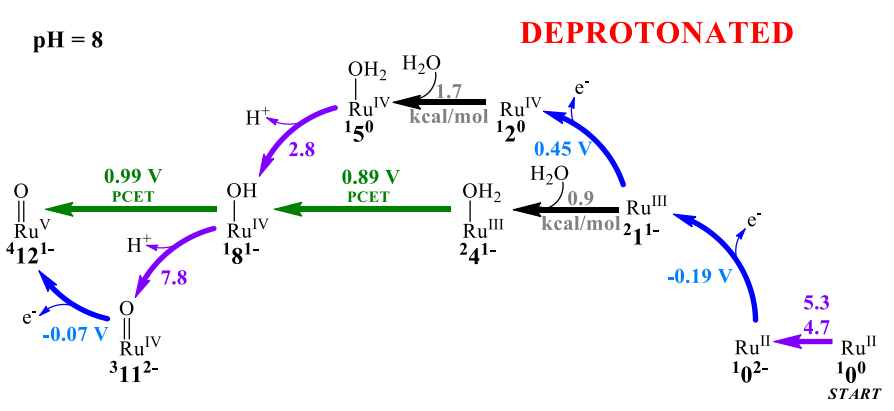

Figure 2. Optimal electrochemical reaction mechanism catalyzed by $\mathbf{B}(=[$ Rull $] 0)$ at $\mathrm{pH}=8$. Green $=$ PCET, blue $=$ oxidation, purple $=$ deprotonation. Species are labelled $\mathbf{X} \mathbf{q}$, where $\mathrm{X}$ indicates spin state and $q$ is the total charge of species $Y$. Full figure in $S I$.

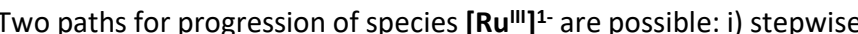
oxidation to $\left[\mathbf{R u}^{\mathbf{l}} \mathbf{V}_{-} \mathrm{OH}_{2}\right]^{\mathbf{0}}$ and then a simple deprotonation to $\left[\mathbf{R} \mathbf{u}^{\mathbf{l} \mathbf{v}}\right.$ $\mathrm{OH}]^{1-}\left(\mathrm{pK}_{\mathrm{a}}=2.8\right)$ and ii) PCET from $\left[\mathrm{Ru}^{\mathrm{lll}-}-\mathrm{OH}_{2}\right]^{1-}$ to $\left[\mathrm{Ru}^{\mathrm{lv}}-\mathrm{OH}\right]^{1-}$ at 0.89 V. The first path, $\left[\mathrm{Ru}^{\prime \prime}\right]^{2-} \rightarrow\left[\mathrm{Ru}^{\prime \prime \prime \prime}\right]^{1-} \rightarrow\left[\mathrm{Ru}^{\mathrm{IV}}\right]^{0} \rightarrow\left[\mathrm{Ru}^{\mathrm{IV}}-\mathrm{OH}_{2}\right]^{0} \rightarrow\left[\mathrm{Ru}^{\mathrm{IV}}-\mathrm{OH}\right]^{1-}$ is the lowest potential pathway and involves two oxidation steps:

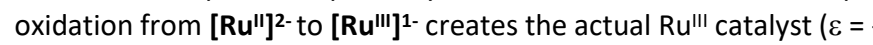
$0.19 \mathrm{~V}$ ), and the second oxidation with $\varepsilon=0.45 \mathrm{~V}$ leads to species $\left[\mathrm{Ru}^{\mathrm{IV}}\right]^{0}$. It interacts with water reaching $\left[\mathrm{Ru}^{\mathrm{IV}}-\mathrm{OH}_{2}\right]^{0}$ in a slightly endergonic process $(\Delta G=1.7 \mathrm{kcal} / \mathrm{mol})$, and finally it deprotonates towards $\left[\mathrm{Ru}^{\mathrm{IV}}-\mathrm{OH}\right]^{1-}$. According to Meyer and Huynh, ${ }^{63,64}$ between electronic pairs such as Ru ${ }^{I I I / I V}$ species $\left[\mathrm{Ru}^{\mathrm{III}}-\mathrm{OH}_{2}\right]^{1-}$ and $\left[\mathrm{Ru}^{\mathrm{IV}}-\mathrm{OH}_{2}\right]^{\mathbf{0}}$, if $\mathrm{pH}<\mathrm{pK}_{\mathrm{a}-\mathrm{IV}}$ oxidation is favored, if $\mathrm{pK}_{\mathrm{a}-\mathrm{III}}<\mathrm{pH}$ deprotonation is favored, and if $\mathrm{pK}_{\mathrm{a}-\mathrm{IV}}<\mathrm{pH}<\mathrm{pK}_{\mathrm{a}-\mathrm{III}}$ PCET is favored. We use this approach to distinguish between paths. Accordingly, in the second

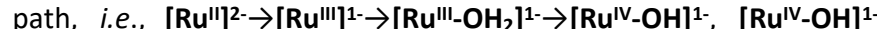
could be reached from [ $\left.\mathrm{Ru}^{\mathrm{III}}-\mathrm{OH}_{2}\right]^{1-}$ through a PCET at $0.89 \mathrm{~V}\left(\mathrm{pK}_{\mathrm{a}-\mathrm{IV}}=\right.$ 2.8 and $\mathrm{pK}_{\mathrm{a}-\mathrm{III}}=9.2$ ). It is quite likely that the two paths described above for the oxidation of $\mathrm{H}_{2} \mathrm{O}-\mathrm{Ru}^{\text {III }}$ species [ $\left.\mathrm{Ru}^{\text {III }}\right]^{1-}$ are operative. We cannot favor one or the other with only the thermodynamic data collected. Our findings match those of Concepcion et al.20a If we consider experimental data, such as the voltammograms from Grotjahn et al. (see SI), there is no peak at $0.45 \mathrm{~V}$, thus the PCET is likely to be the preferred path. Finally, $R u^{V}$ species $\left[R^{v}=0\right]^{1-}$ is reached through a PCET at $0.99 \mathrm{~V}$ or through a deprotonation $\left(\mathrm{pK}_{\mathrm{a}}=\right.$ 7.8) towards $\left[\mathrm{Ru}^{\mathrm{IV}}=\mathbf{=}\right]^{2-}$ followed by an oxidation at $-0.07 \mathrm{~V}$. Due to the similar values of $\mathrm{pK}_{\mathrm{a}}$ and the medium $\mathrm{pH}$, we cannot distinguish between these two routes to $\mathrm{Ru}^{\mathrm{v}}$ species $\left[\mathrm{Ru}^{\mathrm{v}}=\mathbf{0}\right]^{1-.65}$ Since experiments were done at $\mathrm{pH}=7$, we believe that once again, the PCET prevailed over the deprotonation in these experiments. At higher $\mathrm{pHs}$, however, the route through $\left[\mathbf{R u}^{\mathrm{IV}}=\mathbf{0}\right]^{2-}$ could be operative.

Mechanism at $p H$ 1. Turning now to acidic conditions, when CAN becomes the oxidant, the $\mathrm{pH}$ is either close to 1 (using CAN alone) or intentionally started at 1 (using acid media). We performed the same mechanistic analysis at $\mathrm{pH}=1$, where CAN is considered simply as a one electron redox agent providing an overall oxidizing potential of $1.6 \sim 1.7 \mathrm{~V}$ to the medium.

Figure 3 shows that the switch from $\mathrm{pH}=8$ to $\mathrm{pH}=1$ forces some changes to the pathway. Importantly, the identity of the redox steps changes due to the lack of ligand deprotonation. Conversion of [Ru" $]^{0}$ to $\left[\mathbf{R u}^{\text {III-}}-\mathrm{OH}_{2}\right]^{1+}$ can follow two routes: either oxidation to $\left[\mathbf{R u}^{\prime \prime \prime}\right]^{1+}$ with a redox potential of $0.45 \mathrm{~V}$ followed by endergonic water binding $(\Delta \mathrm{G}=5.9 \mathrm{kcal} / \mathrm{mol})$ or water binds [Ru" ${ }^{0}{ }^{0}$ to form $\left[\mathbf{R u}^{\prime \prime}-\mathrm{OH}_{2}\right]^{0}$ $(\Delta \mathrm{G}=2.5 \mathrm{kcal} / \mathrm{mol})$ followed by oxidation $(\varepsilon=0.60 \mathrm{~V})$. As previously stated, we believe that the catalyst first oxidizes, and then binds the water molecule following the $\left[\mathbf{R u}^{\prime \prime}\right]^{0} \rightarrow\left[\mathbf{R u}^{\prime \prime \prime}\right]^{1+} \rightarrow\left[\mathbf{R u}^{\prime \prime \prime}-\mathrm{OH}_{2}\right]^{1+}$ path Next, two PCET steps lead to $\mathrm{Ru}^{\vee}$ oxo species $\left[\mathrm{Ru}^{\mathrm{v}}=\mathbf{0}\right]^{1+}$. The first PCET step leading from Rulll to $\mathrm{Ru}^{\mathrm{IV}}$ is predicted to be more emanding: $1.03 \mathrm{~V}, 0.14 \mathrm{~V}$ higher than for the Rulll to RulV oxidation at $\mathrm{pH}=8$, and $0.28 \mathrm{~V}$ higher than for the similar step for the carboxylate counterpart. ${ }^{66}$ 
pH $=1$

BIPROTONATED

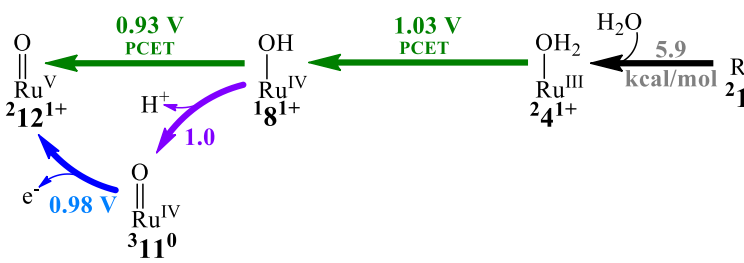

Figure 3. Optimal mechanism for $\mathbf{B}$ at $\mathrm{pH}=1$. Green arrows for PCETs, blue for oxidation states, and purple for $\mathrm{pK}_{\mathrm{a}}$. Species are labelled ${ }^{\mathrm{X}} \mathbf{q}$ where $\mathrm{X}$ indicates spin state and $\mathrm{q}$ is the total charge of species $\mathrm{Y}$. Full figure in SI.

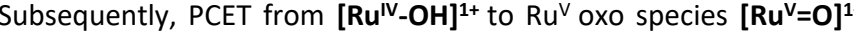
occurs at $0.93 \mathrm{~V}$. Alternatively, $\left[\mathrm{Ru}^{\mathrm{lV}}-\mathrm{OH}\right]^{1+}$ can deprotonate first ( $\mathrm{pK}$ $=1$ ) and then by oxidation $(0.98 \mathrm{~V})$ species $\left[\mathrm{Ru}^{\mathrm{V}}=\mathbf{0}\right]^{1+}$ is reached. Due to the similarity between the $\mathrm{pK}_{\mathrm{a}}$ and the $\mathrm{pH}$ of the medium, thus once more, we cannot distinguish between the two paths from [Ru'v $\mathbf{O H}]^{1+}$ to $\left[\mathbf{R u}^{\mathrm{V}}=\mathbf{O}^{1+}\right.$ with computational data alone. Experimentally cyclic voltammograms show activity at $1.4 \mathrm{~V}$. This is far from the 1.03 $\checkmark$ found computationally. An explanation to this difference can be found by looking at the $\mathrm{pK}_{\mathrm{a}}$ of the phosphonates in each complex. We found that $\left[\mathrm{Ru}^{\prime \prime \prime}-\mathrm{OH}_{2}\right]^{1+}$ has a $\mathrm{pK}_{\mathrm{a}}$ for the deprotonation of one of the phosphonates of $0.2,\left[\mathrm{Ru}^{\mathrm{IV}}-\mathrm{OH}\right]^{1+}$ of 0.8 , and $\left[\mathrm{Ru}^{\mathrm{V}}=\mathrm{O}^{1+}\right.$ of 1.1 . What this means is that compounds $\left[\mathrm{Ru}^{\mathrm{III}}-\mathrm{OH}_{2}\right]^{1+}$ and $\left[\mathrm{Ru}^{\mathrm{IV}} \mathrm{v}_{-} \mathrm{OH}\right]^{1+}$ spontaneously become $\left[\mathrm{Ru}^{\mathrm{III}}-\mathrm{OH}_{2}\right]^{0}$ and $\left[\mathrm{Ru}^{\mathrm{IV}}-\mathrm{OH}\right]^{0}$ with one of thei phosphonates deprotonated at $\mathrm{pH}=1$. If one looks at the PCETs of the monoprotonated phosphonate catalyst (Figure 4), they are 1.26 $\mathrm{V}$ and $1.21 \mathrm{~V}$, respectively, which are much closer to the experimental 1.4 V. We will come back to this issue later.

Because the III/IV redox couple of cerium is in the range of 1.6-1.7 V when CAN is used to drive water oxidation, the proposed PCET a $1.26 \mathrm{~V}$ can occur. However, we must consider kinetics. Predicting the speed of a redox process is not an easy task. A useful generalization is that redox couples driven with overpotentials that surpass $0.6 \mathrm{~V}$ usually occur at a fast rate. ${ }^{67}$ In our case, for the $\left[\mathbf{R u}^{\prime \prime \prime}-\mathbf{O H}_{2}\right]^{0}$ to $\left[\mathbf{R u}^{\mathbf{I V}}\right.$ $\mathrm{OH}]^{0}$ PCET reaction, we observe that we have an overpotential of $>0.34 \mathrm{~V}$ (>1.60 V CAN $-1.26 \mathrm{~V}$ PCET). Formation of oxygen from wate with CAN does occur experimentally. This can be explained through the difference between implementation of electrodes vs. CAN; the oxidizing equivalents provided by the polarization of the medium through the electrode surface may not be sufficient, while on the other hand with a large ( $>1000$-fold) excess of CAN the reaction can proceed. Excesses of other stoichiometric oxidants with sufficient oxidation potential such as $\left[\mathrm{Co}^{\prime \prime \prime}\left(\mathrm{H}_{2} \mathrm{O}\right)_{6}\right]^{3+}$ or $\left[\mathrm{Ru}^{\prime \prime \prime}(\text { bipy })_{3}\right]^{3+}$ can perform the same function as CAN.68

Again, we want to compare our redox potential results for the bda catalyst $\mathbf{A}$ at $\mathrm{pH}=1$ (two PCETs of 0.75 and $1.01 \mathrm{~V}$ ), ${ }^{66}$ with the results given in Figure 4 . The bda catalyst $A$ requires less positive potentials than $B(1.26$ and $1.21 \mathrm{~V})$, and furthermore, the PCET at most positive potential for $\mathbf{A}$ is $\mathrm{Ru}^{\mathrm{IV}}-\mathrm{OH}$ to $\mathrm{Ru}^{\mathrm{V}}=0,{ }^{15}$ while in the case of $\mathbf{B}$ the highest potential PCET is the transition of $\left[\mathrm{Ru}^{\mathrm{III}}-\mathrm{OH}_{2}\right]$ to $\left[\mathrm{Ru}^{\mathrm{IV}}-\mathrm{OH}\right]$ which again is consistent with the more sluggish performance of $B$ compared to that of $\mathbf{A}$.

\section{$\mathbf{p H}=\mathbf{1} \quad$ MONOPROTONATED}

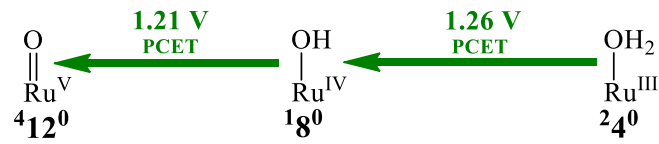

Figure 4. Monoprotonated phosphonate mechanism for $\mathbf{B}$ at $\mathrm{pH}=1$ Species are labelled ${ }^{X} Y q$, where $X$ indicates spin state and $q$ is the total charge of species $Y$. Full figure in SI.

$2 M$ vs WNA pathways. Scheme 2 represents the comparative between pathways. Starting from the mechanism at $\mathrm{pH}=8$ and considering the $\mathrm{O}-\mathrm{O}$ bond formation, $12 \mathrm{M}$, approach of two molecules of intermediate $\left[\mathbf{R u}^{\mathbf{v}}=\mathbf{O}\right]^{1-}$ to form $\left[\mathbf{R} \mathbf{u}^{\mathrm{III}}-\mathbf{O} \mathbf{0 0}\right]^{2-}$ turns out to be the rate determining step (rds). ${ }^{69}$ With a Gibbs energy barrier of $19.7 \mathrm{kcal} / \mathrm{mol}$, this transition state (with an O-O distance of $1.884 \AA$ ) is $7.3 \mathrm{kcal} / \mathrm{mol}$ more kinetically demanding than the corresponding one in the catalysis by Ru(bda), explaining the slower catalysis of the bisphosphonate Ru catalyst. ${ }^{66}$ As a matter of fact, we have also tested whether an initial adduct is formed, but since the adduct is 13 $\mathrm{kcal} / \mathrm{mol}$ higher than two $\left[\mathrm{Ru}^{\mathrm{V}}=\mathbf{0}\right]^{1-}$ units, we believe that this potential adduct is not a relevant species in the reaction mechanism. It is important to note that the I2M product [Ru'II-OO] ${ }^{2-}$ is disfavored by $5.7 \mathrm{kcal} / \mathrm{mol}$ whereas in the case of the Ru(bda) the analogous species is slightly favored by $0.3 \mathrm{kcal} / \mathrm{mol} .{ }^{66}$ We suggest that bonding of two negatively charged molecules of $\left[R^{v} \mathbf{v}=0\right]^{1-}$ is particularly disfavored by Coulombic repulsion in the bisphosphonate Ru catalyst because of the phosphonate oxygens, which are more negatively charged than the ones at the bda carboxylates.

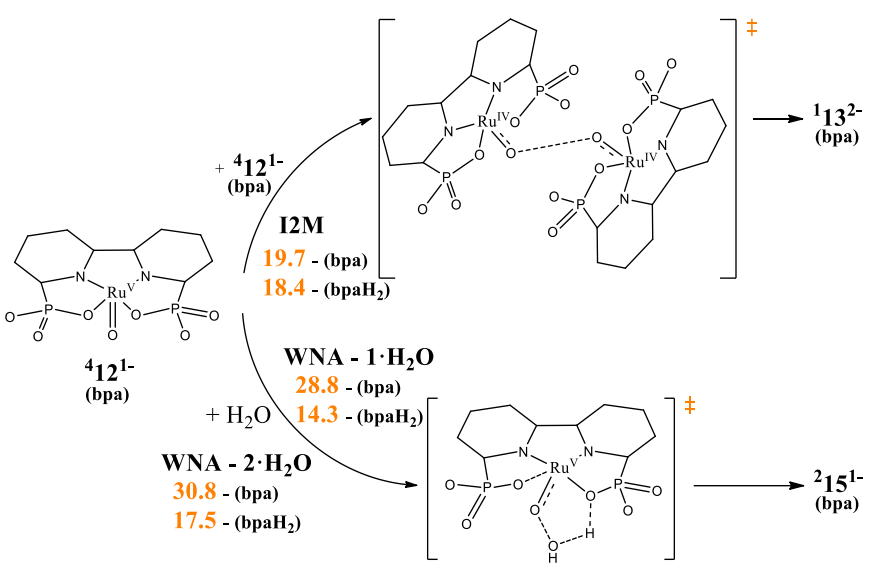

Scheme 2. 12M and WNA mechanisms pathways (with 1 or 2 assisting water molecules) for the deprotonated (bpa at $\mathrm{pH}=8$ ) and protonat (bpa non-interacting hydrogens removed for clarity). Gibbs energy barriers $(\mathrm{kcal} / \mathrm{mol})$ in orange.

Then, cleavage of one of the $\mathrm{Ru}(\mathrm{bpa})$ halves recovers [ $\left.\mathrm{Ru}^{\mathrm{III}}\right]^{1-}$ and we

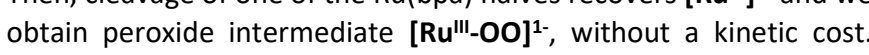

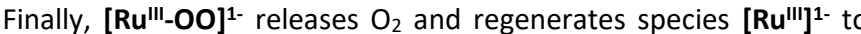
complete the catalytic cycle. Considering a WNA pathway from $\left[\mathbf{R u}^{\mathrm{V}}=\mathbf{0}\right]^{1-}$, we tested Concepcion's proposal of phosphonate-assisted water nucleophilic attack, but we found the transition state (TS) for this interaction at $28.8 \mathrm{kcal} / \mathrm{mol}, 9.1 \mathrm{kcal} / \mathrm{mol}$ higher in energy than the TS for the 12M pathway. The barrier for the WNA does not decrease by the assistance of an additional second water molecule 
(Scheme $2, \Delta \mathrm{G}^{\ddagger}=30.8 \mathrm{kcal} / \mathrm{mol}$ ), however then owning a dangling phosphonate. Neither the structures predicted by Concepcion et al, ${ }^{2}$ where both phosphonate ligands provided a Ru-O bond each one could help here to decrease the energy barrier. Hence we conclude that the WNA pathway is not competitive under at $\mathrm{pH}=8$. For further details of the I2M and WNA, mechanisms check the $\mathrm{SI}$.

As to the mechanism at $\mathrm{pH}=1$, at the stage of $\mathrm{Ru}^{\vee}$ oxo specie $\left[\mathbf{R u}^{\mathrm{V}}=\mathrm{O}^{\mathbf{1 +}}\right.$, we tested the hypothesis of water nucleophilic attack (WNA) that has been proposed by groups of Grotjahn and Concepcion. We calculate that WNA on $\mathrm{Ru}^{\mathrm{V}}$ oxo species $\left[\mathrm{Ru}^{\mathrm{V}}=\mathbf{0}\right]^{1+}$ with one and two assisting water molecules displays Gibbs energy barriers of 14.3 and $17.5 \mathrm{kcal} / \mathrm{mol}$, respectively, whereas in the $12 \mathrm{M}$ pathway increases to $18.4 \mathrm{kcal} / \mathrm{mol}$. To point out that the transition state of the $12 \mathrm{M}$ process has a short O-O distance of $1.695 \AA$ and displays a closed-shell singlet character already, like the next intermediate. This indicates that at $\mathrm{pH}=1$ the WNA is the preferred pathway. Nevertheless, the full WNA reaction mechanism requires the two deprotonation steps depicted in Figure 5. However, the $\mathrm{pK}_{\mathrm{a}}$ of species [ $\left.\mathbf{R u}^{\prime \prime \prime}-\mathrm{OOH}_{2}\right]^{1+}$ and $\left[\mathrm{Ru}^{\prime \prime \prime}-\mathbf{O O H}\right]^{0}$ are higher than the $\mathrm{pH}$, and thus these species do not deprotonate. With this information, it is clear that while water may be able to bind to the $\mathrm{Ru}=\mathrm{O}$ center, it wil not deprotonate. Overall, experiments show that the I2M pathway cannot occur, yet, the computational data shows that it cannot undergo WNA either.

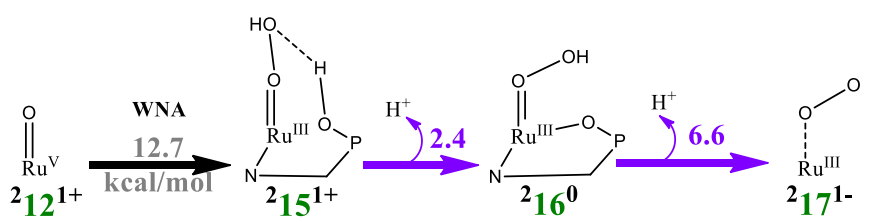

Figure 5. Liberation of $\mathrm{O}_{2}$ through WNA for the $\mathrm{bpaH}_{2}$ catalyst at $\mathrm{pH}$ $=1$. Gibbs reaction energy $(\mathrm{kcal} / \mathrm{mol})$ in grey, $\mathrm{pK}_{\mathrm{a}}$ for deprotonations in purple.

There is only one option left that fulfills experimental results: $12 \mathrm{M}$ pathway with one $\mathrm{Ru}=\mathrm{O}$ catalyst molecule and one ceric ammonium nitrate molecule. Experiments show first order kinetics according to the catalyst and as this Ru-CAN implies, it accomplishes this experimental result. Second, the reaction progresses only with CAN and, to the best of our knowledge, no other oxidants were tested. Applying an external potential does not reproduce the catalytic activity with it, which indicates that the CAN plays an important role besides being an oxidant. This also explains why at more basic $\mathrm{pH}$ there is no catalytic activity; CAN is not suitable at neutral $\mathrm{pH}$ because it would precipitate.

Finally, let us mention that we tried to find a possible $12 \mathrm{M}$ pathway involving the CAN. To do so, we searched for an initial structure of the CAN species. However, despite our efforts, we could not find an energetically accessible structure for CAN showing reduction potentials close to $1.6 \sim 1.7 \mathrm{~V}$ and, therefore, we were unable to explore a possible the formation of a Ru-Ce dimer (see Figure S6 in the $\mathrm{SI})$.

Computation vs experiments. In this section, we perform comparison between experimental and computational data. The first experimental data we can compare is the cyclic voltammetries given by Grotjahn et al..$^{25}$ and Xie et al. ${ }^{26}$ (see SI) that shows the existence of two peaks: $0.48 \mathrm{~V}$ and $1.40 \mathrm{~V}$ at $\mathrm{pH}=1$ and $0.17 \mathrm{~V}$ and $1.25 \mathrm{~V}$ at $\mathrm{pH}=7$. Starting from the $\mathrm{pH}=1$ mechanism, we can assign the experimental $0.48 \mathrm{~V}$ to the $0.45 \mathrm{~V}$ calculated oxidation that refers to $\left[\mathrm{Ru}^{\prime \prime}\right]^{0} \rightarrow\left[\mathrm{Ru}^{\prime \prime \prime}\right]^{1+}$. For the peak at $1.40 \mathrm{~V}$, we have to consider the two PCET that occur in the monoprotonated mechanism (bpaH, Fig. 4) at electropotentials close to $1.25 \mathrm{~V}$, which we believe responsible for the experimental peak at $1.40 \mathrm{~V}$. Last but not least, due to the close proximity for both PCET potentials, the experimental results show only one peak because they overlap. There is another possibility: the oxidation of $\left[\mathrm{Ru}^{\mathrm{II}}\right]^{1-} \rightarrow\left[\mathrm{Ru}^{\mathrm{IV}}\right]^{0}$ calculated at $0.45 \mathrm{~V}$ yet, there is no experimental peak at this potential. We believe that this oxidation does not occur due to the kinetic reasons. Finally, at $\mathrm{pH}=8$, we can see experimentally two peaks at $0.17 \mathrm{~V}$ and $1.25 \mathrm{~V}$. The first peak coincides with our calculated $-0.19 \mathrm{~V}$ (Fig. 2). As for the second peak at $1.25 \mathrm{~V}$ we believe once again that the two PCET [Ru'II-OH $]^{1-} \rightarrow$ $\left[\mathrm{Ru}^{\mathrm{IV}}-\mathrm{OH}\right]^{1-}$ and $\left[\mathrm{Ru}^{\mathrm{IV}}-\mathrm{OH}\right]^{1-} \rightarrow\left[\mathrm{Ru}^{\mathrm{V}}=\mathbf{O}\right]^{1-}$ are responsible for this peak. As a whole, the proposed reaction mechanisms that agree with experimental evidences are depicted in Figure 6.
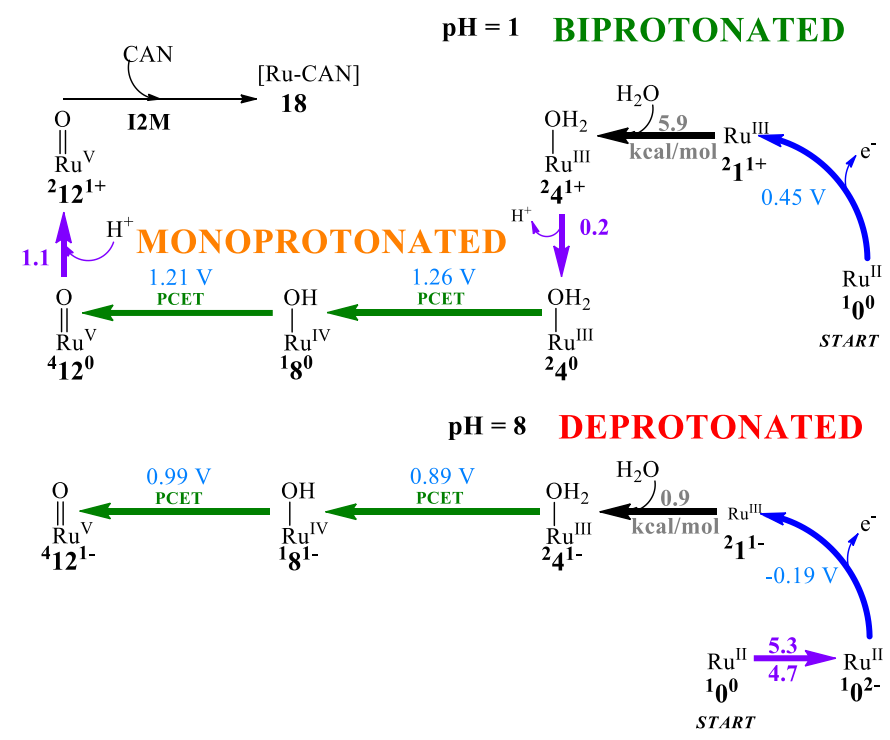

Figure 6. Proposed final mechanisms at both $\mathrm{pH}$ for $\mathrm{bpaH}_{2} / \mathrm{bpaH}$ and bpa catalysts.

\section{Conclusions}

We have computationally studied the water oxidation catalysis for the bisphosphonate bispyridine Ru catalyst B according to the experiments performed by the Grotjahn and Concepcion groups. The study is divided into two different $\mathrm{pH}$ regimes, basic $(\mathrm{pH}=8)$ and acidic $(\mathrm{pH}=1)$. For $\mathrm{pH}=8$, the reaction mechanism follows an $12 \mathrm{M}$ pathway that is the rds with a barrier of $19.7 \mathrm{kcal} / \mathrm{mol}$. This Gibbs energy barrier is higher in energy than the one found at $11.4 \mathrm{kcal} / \mathrm{mol}$ for its carboxylate counterpart, studied previously by some of us. ${ }^{66}$ The WNA is not competitive at $\mathrm{pH}=8$ due to a Gibbs barrier of 28.8 $\mathrm{kcal} / \mathrm{mol}$. At $\mathrm{pH}=1$, the WNA mechanism with a barrier of 14.3 $\mathrm{kcal} / \mathrm{mol}$ is preferred over the $12 \mathrm{M}$ with a barrier of $18.4 \mathrm{kcal} / \mathrm{mol}$. However, the WNA pathway at $\mathrm{pH}=1$ for the $\mathrm{O}_{2}$ liberation involves two deprotonations that are not possible at $\mathrm{pH}=1$. This means that WNA cannot progress after binding the water molecule. Considering this, we hypothesize a third pathway, an 12M that combines the Ru catalyst and CAN. Despite several tries, we did not find a suitable structure for CAN to do a detailed work of this mechanism. Nevertheless, all the experimental and computational results lead us 
to believe that this is indeed the mechanism, since it fulfills experimental evidences. It has first-order kinetics to the Ru catalys and it works at $\mathrm{pH}=1$ with CAN but not with external potentials.

\section{Conflicts of interest}

There are no conflicts to declare.

\section{Acknowledgements}

J.A.L.U. thanks Universitat de Girona for a IFUdG2017 PhD fellowship. A.P. is a Serra Húnter Fellow. A.P. and M.S. thank the
Ministerio de Economía y Competitividad (MINECO) of Spain for projects CTQ2014-59832-JIN, PGC2018-097722-B-I00 and CTQ2017-85341-P; Generalitat de Catalunya for project 2017SGR39, Xarxa de Referència en Química Teòrica i Computacional, and ICREA Academia prize 2014 to M.S. and 2019 to A.P. D.B.G. and J.M.K. were supported during writing and editing by the U.S. Department of Energy, Office of Science, Office of Basic Energy Sciences, under Award DE-SC0018310. We thank Javier J. Concepcion for helpful discussions about the role of sacrificial oxidants and mechanism.

\section{Notes and references}

(1) K. Wang, H. Chen, Y. Hua, Y. Tong, Y. Wang and S. Song, LayerStacking Porous $W C_{x}$ Nanoparticles on Carbon Cloth as SelfSupported Integrated Electrode for Hydrogen Evolution Reaction. Mater. Today Energy 2018, 10, 343-351.

(2) N. Guo, Y. Zeng, H. Li, X. Xu, H. Yu and H. Han, Novel Mesoporous $\mathrm{TiO}_{2} @ g-\mathrm{C}_{3} \mathrm{~N}_{4}$ Hollow Core@Shell Heterojunction with Enhanced Photocatalytic Activity for Water Treatment and $\mathrm{H}_{2}$ Production Undress Simulated Sunlight. J. Hazard. Mater. 2018, 353, 80-88.

(3) E. R. López, F. Dorado and A. de Lucas-Consuegra, Electrochemica Promotion for Hydrogen Production via Ethanol Steam Reforming Reaction. Appl. Catal. B: Environ. 2019, 243, 355-364.

(4) a) Y.-Y. Li, C. Gimbert, A. Llobet, P. E. M. Siegbahn and R.-Z. Liao, Quantum Chemical Study of the Mechanism of Water Oxidation Catalyzed by a Heteronuclear $\mathrm{Ru}_{2} \mathrm{Mn}$ Complex. ChemSusChem 2019, 12, 1101-1110. b) L. Vigara, M. Z. Ertem, N. Planas, F. Bozoglian, N. Leidel, H. Dau, M. Haumann, L. Gagliardi, C. J. Cramer, and A. Llobet, Experimental and Quantum Chemical Characterization of the Water Oxidation Cycle Catalysed by [Ru"(damp)(bpy) $\left.\left(\mathrm{H}_{2} \mathrm{O}\right)\right]^{2+}$. Chem. Sc 2012, 3, 2576-2586.

(5) a) L. Wang, D. W. Shaffer, G. F. Manbeck, D. E. Polyansky and J. J. Concepcion, High-Redox-Potential Chromophores for Visible-LightDriven Water Oxidation at Low pH. ACS Catal. 2019, 10, 580-585. b) D. Wang, L. Wang, M. D. Brady, C. J. Dares, G. J. Meyer, T. J. Meye and J. J. Concepcion, Self-Assembled Chromophore-Catalyst Bilaye for Water Oxidation in a Dye-Sensitized Photoelectrosynthesis Cell. J. Phys. Chem. C 2019, 123, 30039-30045.

(6) J. A. Gilbert, D. S. Eggleston, W. R. Murphy, D. A. Geselowitz, S. W. Gersten, D. J. Hodgson and T. J. Meyer, Structure and Redox Properties of the Water-Oxidation Catalys $\left[(\mathrm{bpy})_{2}\left(\mathrm{OH}_{2}\right) \mathrm{RuORu}\left(\mathrm{OH}_{2}\right)(\mathrm{bpy})_{2}\right]^{4+}$. J. Am. Chem. Soc. 1985, 107, 3855-3864.

(7) S. W. Gersten, G. J. Samuels and T. J. Meyer, Catalytic Oxidation of Water by an Oxo-Bridged Ruthenium Dimer. J. Am. Chem. Soc. 1982, 104, 4029-4030.

(8) L. Duan, C. M. Araujo, M. S. G. Ahlquist and L. Sun, Highly efficient and robust molecular ruthenium catalysts for water oxidation. Proc Nat. Acad. Sci. 2012, 109, 15584-15588.
(9) J. J. Concepcion, J. W. Jurss, J. L. Templeton and T. J. Meyer, One Site is Enough. Catalytic Water Oxidation by $\left[\mathrm{Ru}(\mathrm{tpy})(\mathrm{bpnm})\left(\mathrm{OH}_{2}\right)\right]^{2+}$ and $\left[\mathrm{Ru}(\mathrm{tpy})(\mathrm{bpz})\left(\mathrm{OH}_{2}\right)\right]^{2+}$. J. Am. Chem. Soc. 2008, 130, 16462-16463.

(10) S. Romain, F. Bozoglian, X. Sala and A. Llobet, Oxygen-Oxygen Bond Formation by the Ru-Hbpp Water Oxidation Catalyst Occurs Solely via an Intramolecular Reaction Pathway. J. Am. Chem. Soc. 2009, 131, 2768-2769.

(11) J. F. Hull, D. Balcells, J. D. Blakemore, C. D. Incarvito, O. Eisenstein, G. W. Brudvig and R. H. Crabtree, Highly Active and Robust Cp* Iridium Complexes for Catalytic Water Oxidation. J. Am. Chem. Soc. 2009, 131, 8730-8731.

(12) N. D. McDaniel, F. J. Coughlin, L. L. Tinker and S. Bernhard, Cyclometalated Iridium(III) Aquo Complexes: Efficient and Tunable Catalysis for the Homogeneous Oxidation of Water. J. Am. Chem. Soc. 2008, 130, 210-217.

(13) L. Duan, A. Fischer, Y Xu and L. Sun, Isolated Seven-Coordinate $\mathrm{Ru}(\mathrm{IV})$ Dimer Complex with $\mathrm{HOHOH}^{-}$Bridging Ligand as an Intermediate for Catalytic Water Oxidation. J. Am. Chem. Soc. 2009, 131, 10397-10399.

14) J. Nyhlén, L. Duan, B. Akermark, L. Sun and T. Privalov, Evolution of $\mathrm{O}_{2}$ in a Seven-Coordinate Rulv Dimer Complex with a $[\mathrm{HOHOH}]$ Bridge: A Computational Study. Angew. Chem. Int. Ed. 2010, 49, 1773-1777.

(15) L. Duan, F. Bozoglian, S. Mandal, B. Stewart, T. Privalov, A. Llobet and L. Sun, A Molecular Ruthenium Catalyst with Water-Oxidation Activity Comparable to that of Photosystem II. Nat. Chem. 2012, 4 418-423.

(16) a) A. Poater, J. Mola, A. Gallegos Saliner, I. Romero, M. Rodríguez, A. Llobet and M. Solà, Mechanistic Theoretical Insight of Ru(II) Catalysts with a Meridional-Facial Bpea Fashion Competition. Chem. Phys. Lett. 2008, 458, 200-204. b) J. A. Luque-Urrutia and A. Poater, The Fundamental non Innocent Role of Water for the Hydrogenation of Nitrous Oxide by PNP pincer Ru-based catalysts. Inorg. Chem. 2017, 56, 14383-14387. c) M. Gil-Sepulcre, J. C. Axelson, J. Aguiló, J.; L. Solà-Hernández, L. Francàs, A. Poater, L. Blancafort, J. BenetBuchholz, G. Guirado, L. Escriche, A. Llobet, R. Bofill and X. Sala, Synthesis and Isomeric Analysis of Ru" Complexes Bearing 2 Pentadentate Scaffolds. Inorg. Chem. 2016, 55, 11216-11229. d) S. 
Escayola, M. Solà and A. Poater, Mechanism of the Facile Nitrous Oxide fixation by Homogeneous Ruthenium Hydride Pincer Catalysts. Inorg Chem. 2020, 59, 9374-9383.

(17) R. Matheu, M. Z. Ertem, M. Pipelier, J. Lebreton, D. Dubreuil, J. Benet-Buchholz, X. Sala, A. Tessier and A. Llobet, The Role of Seven Coordination in Ru-Catalyzed Water Oxidation. ACS Catal. 2018, 8 , 2039-2048.

(18) R. Matheu, S. Neudeck, F. Meyer, X. Sala and A. Llobet, Foot of the Wave Analysis for Mechanistic Elucidation and Benchmarking Applications in Molecular Water Oxidation Catalysis. ChemSusChem 2016, 9, 3361-3369.

(19) a) M. Schulze, V. Kunz, P. D. Frischmann and F. A. Würthner, Supramolecular Ruthenium Macrocycle with High Catalytic Activity for Water Oxidation that Mechanistically Mimics Photosystem II. Nat. Chem. 2016, 8, 576-583. b) C. W. Cady, R. H. Crabtree and G. W. Brudvig, Functional Models for the Oxygen-Evolving Complex of Photosystem II. Coord. Chem. Rev. 2008, 252, 444-455.

(20) a) Y. Xie, D. W. Shaffer and J. J. Concepcion, O-O Radical Coupling: From Detailed Mechanistic Understanding to Enhanced Water Oxidation Catalysis. Inorg. Chem. 2018, 57, 10533-10542. b) R Matheu, A. Ghaderian, L. Francàs, P. Chernev, M. Z. Ertem, J. BenetBuchholz, V. S. Batista, M. Haumann, C. Gimbert-Suriñach, X. Sala and A. Llobet, Behavior of Ru-bda Water-Oxidation Catalyst in Low Oxidation States. Chem. Eur. J. 2018, 24, 12838-12847. c) Q. Daniel, L. Wang, L. Duan, F. Li and L. Sun, Tailored Design of Ruthenium Molecular Catalyst with 2,2'-Bypyridine-6,6'-dicarboxylate and Pyrazole Based Ligands for Water Oxidation. Dalton Trans. 2016, 45 14689-14696.

(21) S. Zhan, D. Martensson, M. Purg, S. C. L. Kamerlin and M. S. G. Ahlquist, Capturing the Role of Explicit Solvent in the Dimerization of $\mathrm{Ru}^{\mathrm{v}}$ (bda) Water Oxidation Catalysts. Angew. Chem. Int. Ed. 2017, 56, 6962-6965.

(22) R. Matheu, M. Z. Ertem, C. Gimbert-Suriñach, X. Sala and A. Llobet, Seven Coordinated Molecular Ruthenium-Water Oxidation Catalysts: a Coordination Chemistry Journey. Chem. Rev. 2019, 119, 34533471.

(23) B. Zhang and L. Sun, Ru-bda: Unique Molecular Water-Oxidation Catalysts with Distortion Induced Open Site and Negatively Charged Ligands. J. Am. Chem. Soc. 2019, 141, 5565-5580.

(24) J. J. Concepcion, D. K. Zhong D. J. Szalda, J. T. Muckerman and E. Fujita, Mechanism of Water Oxidation by $\left[\mathrm{Ru}(\mathrm{bda})(\mathrm{L})_{2}\right]$ : the Return of the "Blue Dimer" Chem. Commun. 2015, 51, 4105-4108.

(25) J. M. Kamdar, D. C. Marelius, C. E. Moore, A. L. Rheingold, D. K. Smith and D. B. Grotjahn, Ruthenium Complexes of 2,2'-bipyridine-6, $6^{\prime}$ diphosphonate Ligands for Water Oxidation. ChemCatChem 2016, 8 3045-3049.

(26) Y. Xie, D. W. Shaffer, A. Lewandowska-Andralojc, D. J. Szalda and J. J. Concepcion, Water Oxidation by Ruthenium Complexes Incorporating Multifunctional Bipyridil Diphosphonate Ligands. Angew. Chem. Int. Ed. 2016, 55, 8067-8071.

(27) a) R. Matheu, A. Ghaderian, L. Francàs, P. Chernev, M. Z. Ertem, J. Benet-Buchholz, V. S. Batista, M. Haumann, C. Gimbert-Suriñach, X. Sala and A. Llobet, Behavior of Ru-bda Water-Oxidation Catalysts in Low Oxidation States. Chem. Eur. J. 2018, 24, 12838-12847. b) C. J. Richmond, S. Escayola and A. Poater, Axial Ligand Effects of Ru-BDA

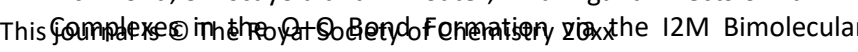
Mechanism in Water Oxidation Catalysis. Eur. J. Inorg. Chem. 2019 2093-2100.

(28) V. Sridharan and J. C. Menéndez, Cerium(IV) Ammonium Nitrate as Catalyst in Organic Synthesis. Chem. Rev. 2010, 110,3805-3849.0
Formation by the $\mathrm{O}_{2}$-Evolving Complex in Photosystem II. Science 1999, 283, 1524-1527.

(31) T. Kikuchi and K. Tanaka, Mechanistic Approaches to Molecular Catalysts for Water Oxidation. Eur. J. Inorg. Chem. 2014, 607-618.

(32) A. R. Parent, R. H. Crabtree and G. W. Brudvig, Comparison of Primary Oxidants for Water-Oxidation Catalysis. Chem. Soc. Rev. 2013, 42, 2247-2252.

(33) Z. Codolà, I. Gamba, F. Acuña-Parés, C. Casadevall, M. Clémancey, J. M. Latour, J. M. Luis, J. Lloret-Fillol and M. Costas, Design of Iron Coordination Complexes as Highly Active Homogenous Water Oxidation Catalysts by Deuteration of Oxidation-Sensitive Sites. J. Am. Chem. Soc. 2019, 141, 323-333.

(34) A. Mills, Heterogeneous Redox Catalysts for Oxygen and Chlorine Evolution. Chem. Soc. Rev. 1989, 18, 285-316.

(35) Z. Codolà, L. Gómez, S. T. Kleespies, L. Que Jr, M. Costas and J. LloretFillol, Evidence for an Oxygen Evolving Iron-oxo-cerium Intermediate in Iron-catalysed Water Oxidation. Nat. Commun. 2015, 6, 5865.

(36) A. Bucci, G. Menendez Rodriguez, G. Bellachioma, C. Zuccaccia, A. Poater, L. Cavallo and A. Macchioni, An Alternative Reaction Pathway for Iridium-Catalyzed Water Oxidation Driven by Cerium Ammonium Nitrate (CAN). ACS Catal. 2016, 6, 4559-4563.

(37) M. Yoshida, S. Masaoka, J. Abe and K. Sakai, Catalysis of Mononuclear Aquaruthenium Ccomplexes in Oxygen Evolution from Water: A new Radical Coupling Path using Hydroxocerium(IV) Species. Chem. Asian J. 2010, 5, 2369-2378.

(38) Angeles-Boza, A. M.; Ertem, M. Z.; Sarma, R.; Ibañez, C. H.; Maji, S.; Llobet, A.; Cramer, C. J.; Roth, J. P. Competitive Oxygen-18 Kinetic Isotope Effects Expose $\mathrm{O}-\mathrm{O}$ Bond Formation in Water Oxidation Catalysis by Monomeric and Dimeric Ruthenium Complexes. Chem Sci. 2014, 5, 1141-1152.

(39) a) S. Roeser, F. Bozoglian, C. J. Richmond, A. B. League, M. Z. Ertem, L. Francàs, P. Miró, J. Benet-Buchholz, C. J. Cramer and A. Llobet, Water Oxidation Catalysis with Ligand Substituted Ru-bpp Type Complexes. Catal. Sci. Technol. 2016, 6, 5088-5101. b) A. Poater Environmental Friendly Fe Substitutive of Ru in Water Oxidation Catalysis. Catal. Commun. 2014, 44, 2-5.

(40) D. W. Shaffer, Y. Xie and J. J. Concepcion, O-O Bond Formation in Ruthenium-Catalyzed Water Oxidation: Single-Site Nucleophilic Attack: Vs. O-O Radical Coupling. Chem. Soc. Rev. 2017, 46, 61706193.

(41) M. Z. Ertem and J. J. Concepcion, Oxygen Atom Transfer as an Alternative Pathway for Oxygen-Oxygen Bond Formation. Inorg. Chem. 2020, 59, 5966-5974.

(42) T. Fan, L. Duan, P. Huang, H. Chen, Q. Daniel, M. S. G. Ahlquist and L. Sun, The Ru-tpc Water Oxidation Catalyst and Beyond: Water Nucleophilic Attack Pathway Versus Radical Coupling Pathway. ACS Catal. 2017, 7, 2956-2966.

(43) I. López, M. Z. Ertem, S. Maji, J. Benet-Buchholz, A. Keidel, U. Kuhlmann, P. Hildebrandt, C. J. Cramer, V. S. Batista and A. Llobet, A Self-Improved Water-Oxidation Catalyst: is One Site Really Enough? Angew. Chem. Int. Ed. 2014, 53, 205-209.

(44) a) S. Zhan and M. S. G. Ahlquist, Dynamics and Reactions of Molecular Ru Catalysts at Carbon Nanotube-Water Interfaces. ACS Catal. 2018, 8, 8642-8648. b) S. Zhan and M. S. G. Ahlquist, Dynamics and Reactions of Molecular Ru Catalysts at Carbon Nanotube-Water Interfaces. J. Am. Chem. Soc. 2018, 140, 7498-7503.

(45) Gaussian 09, Revision E.01, M. J. Frisch, G. W. Trucks, H. B. Schlegel, G. E. Scuseria, M. A. Robb, J. R. Cheeseman, G. Scalmani, V. Barone, B. Mennucci, G. A. Petersson, H. Nakatsuji, M. Caricato, X. Li, H. P. Hratchian, A. F. Izmaylov, J. Bloino, G. Zheng, J. L. Sonnenberg, M. Hada, M. Ehara, K. Toyota, R. Fukuda, J. Hasegawa, M. Ishida, T. Nakajima, Y. Honda, O. Kitao, H. Nakai, T. Vreven, J. A. Montgomery, Jr., J. E. Peralta, F. Ogliaro, M. Bearpark, J. J. Heyd, E. Brothers, K. N. Kudin, V. N. Staroverov, R. Kobayashi, J. Normand, K. Raghavachari, A. Rendell, J. C. Burant, S. S. Iyengar, J. Tomasi, M. Cossi, N. Rega, J. M. Millam, M. Klene, J. E. Knox, J. B. Cross, V. Bakken, C. Adamo, J. 
(56) V. Barone and M. Cossi, Quantum Calculation of Molecular Energies and Energy Gradients in Solution by a Conductor Solvent Model. J. Phys. Chem. A 1988, 102, 1995-2001.

(57) J. Tomasi and M. Persico, Molecular Interactions in Solution: An Overview of Methods Based on Continuous Distributions of the Solvent. Chem. Rev. 1994, 94, 2027-2094.

(58) R.-Z. Liao and P. E. M. Siegbahn, Quantum Chemical Modeling of Homogeneous Water Oxidation Catalysis. ChemSusChem 2017, 10, 4236-4263.

(59) F. Acuña-Parés, Z. Codolà, M. Costas, J. M. Luis and J. Lloret-Fillol Unraveling the Mechanism of Water Oxidation Catalyzed by Nonheme Iron Complexes. Chem. Eur. J. 2014, 20, 5696-5707.

(60) C. P. Kelly, C. J. Cramer and D. G. Truhlar, Single-lon Solvation Free Energies and the Normal Hydrogen Electrode Potential in Methanol,

Jaramillo, R. Gomperts, R. E. Stratmann, O. Yazyev, A. J. Austin, R. Cammi, C. Pomelli, J. W. Ochterski, R. L. Martin, K. Morokuma, V. G. Zakrzewski, G. A. Voth, P. Salvador, J. J. Dannenberg, S. Dapprich, A. D. Daniels, Ö. Farkas, J. B. Foresman, J. V. Ortiz, J. Cioslowski, and D. J. Fox. Gaussian, Inc., Wallingford CT, 2009

(46) Y. Zhao and D. G. Truhlar, The M06 Suite of Density Functionals for Main Group Thermochemistry, Thermochemical Kinetics, Noncovalent Interactions, Excited States, and Transition Elements: Two New Functionals and Systematic Testing of Four M06-Clas Functionals and 12 Other Functionals. Theor. Chem. Acc. 2008, 120, 215-241.

(47) Y. Zhao and D. G. Truhlar, A New Local Density Functional for MainGroup Thermochemistry, Transition Metal Bonding Thermochemical Kinetics, and Noncovalent Interactions. J. Chem. Phys. 2006, 125, 194101:1-18.

(48) A. Schäfer, H. Horn and R. Ahlrichs, Fully Optimized Contracted Gaussian Basis Sets for Atoms Li to Kr. J. Chem. Phys. 1992, 97, 25712577.

(49) U. Haeusermann, M. Dolg, H. Stoll and H. Preuss, Accuracy of Energy Adjusted Quasirelativistic ab initio Pseudopotentials. Mol. Phys. 1993, 78, 1211-1224.

(50) W. Küchle, M. Dolg, H. Stoll and H. Preuss, Energy-Adjusted Pseudopotentials for the Actinides. Parameter Sets and Test Calculations for Thorium and Thorium Monoxide. J. Chem. Phys. 1994, 100, 7535-7542.

(51) T. Leininger, A. Nicklass, H. Stoll, M. Dolg and P. Schwerdtfeger, The Accuracy of the Pseudopotential Approximation. II. A Comparison of Various Core Sizes for Indium Pseudopotentials in Calculations for Spectroscopic Constants of InH, InF, and InCl. J. Chem. Phys. 1996 105, 1052-1059.

(52) R. L. Martin, P. J. Hay and L. R. Pratt, Hydrolysis of Ferric Ion in Water and Conformational Equilibrium. J. Phys. Chem. A 1998, 102, 35653573.

(53) a) A. Poater, E. Pump, S. V. C. Vummaleti and L. Cavallo, The Right Computational Recipe for Olefin Metathesis with Ru-Based Catalysts: the Whole Mechanism of Ring-Closing Olefin Metathesis. J. Chem Theory Comput. 2014, 10, 4442-4448. b) L. Falivene, Barone, G. Talarico, Unraveling the Role of Entropy in Tuning Unimolecular vs. Bimolecular Reaction Rates: The Case of Olefin Polymerization Catalyzed by Transition Metals. Mol. Catal. 2018, 452, 138-144.

(54) a) M. García-Melchor, M. C. Pacheco, C. Nájera, A. Lledós and G. Ujaque, Mechanistic Exploration of the Pd-Catalyzed Copper-Free Sonogashira Reaction, ACS Catal. 2012, 2, 135-144. b) S. Coufourier Q. Gaignard-Gaillard, J.-F. Lohier, A. Poater, S. Gaillard and J.-L. Renaud, Hydrogenation of $\mathrm{CO}_{2}$, Hydrogenocarbonate, and Carbonate to Formate in Water using Phosphine Free Bifunctional Iron Complexes. ACS Catal. 2020, 10, 2108-2116. c) A. Gómez Suárez, Y. Oonishi, A. R. Martin, S. V. C. Vummaleti, D. J. Nelson, D. B. Cordes, A. M. Z. Slawin, L. Cavallo, S. P. Nolan and A. Poater, O the Mechanism of the Digold(I)-Hydroxide-Catalysed Hydrophenoxylation of Alkynes. Chem. Eur. J. 2016, 22, 1125-1132.

(55) F. Weigend and R. Ahlrichs, Comparative Study of the Chemica Reactivity of Helical Peptide Models for Protein Glycation. Phys. Chem. Chem. Phys. 2005, 7, 3297-3305. 408-422.

(61) J. Schneider, R. E. Bangle, W. B. Swords, L. Troian-Gautier and G. J. Meyer, Determination of Proton-Coupled Electron Transfer Reorganization Energies with Application to Water Oxidation Catalysts. J. Am. Chem. Soc. 2019, 141, 9758-9763.

(62) C. Gimbert-Suriñach, D. Moonshiram, L. Francàs, N. Planas, V. Bernales, F. Bozoglian, A. Guda, L. Mognon, I. López, M. A. Hoque, L. Gagliardi, C. J. Cramer and A. Llobet, Structural and Spectroscopic Characterization of Reaction Intermediates Involved in a Dinuclear Co-Hbpp Water Oxidation Catalyst. J. Am. Chem. Soc. 2016, 138, 15291-15294.

(63) M. H. V. Huyn and T. J. Meyer, Proton-Coupled Electron Transfer Chem. Rev. 2007, 107, 5004-5064.

(64) T. J. Meyer and R. A. Binstead, Hydrogen Atom Transfer between Metal Complex lons in Solution. J. Am. Chem. Soc. 1987, 109, 11, 3287-3297.

(65) D. Lebedev, Y. Pineda-Galvan, Y. Tokimaru, A. Fedorov, N. Kaeffer, C. Copéret and Y. Pushkar, The Key Ru $\mathrm{V}^{\mathrm{V}}=\mathrm{O}$ Intermediate of Site-Isolated Mononuclear Water Oxidation Catalyst Detected by in Situ X-ray Absorption Spectroscopy. J. Am. Chem. Soc. 2018, 140, 451-458.

(66) J. A. Luque-Urrutia, M. Solà and A. Poater, The Influence of the $\mathrm{pH}$ on the Reaction Mechanism of Water Oxidation by a Ru(bda) Catalyst. Catal. Today 2020, DOI: 10.1016/j.cattod.2019.12.005.

(67) a) H. Ezaki, M. Morinaga and S. Watanabe, Hydrogen Overpotential for Transition Metals and Alloys, and its Interpretation Using an Electronic Model. Electrochim. Acta 1993, 38, 557-564. b) G. T. Burstein, A Hundred Years of Tafel's Equation: 1905-2005. Corros. Sci. 2005, 47, 2858-2870.

(68) a) R. Kang, K. Chen, J. Yao, S. Shaik and J. Chen, Probing Ligand Effects on $\mathrm{O}-\mathrm{O}$ Bond Formation of Ru-Catalyzed Water Oxidation: A Computational Survey. Inorg. Chem. 2014, 53, 7130-7136. b) Prof. J. J. Concepcion, personal communication.

(69) a) C. J. Richmond, R. Matheu, A. Poater, L. Falivene, J. BenetBuchholz, X. Sala, L. Cavallo and A. Llobet, Supramolecular Water Oxidation with Ru-bda-Based Catalysts. Chem. Eur. J. 2014, 20, 17282-17286. (b) D. W. Shaffer, Y. Xie, D. J. Szalda and J. J. Concepcion, Manipulating the Rate-Limiting Step in Water Oxidation Catalysis by Ruthenium Bipyridine-Dicarboxylate Complexes. Inorg. Chem. 2016, 55, 12024-12035. 